\title{
Inheritance of some fertility traits in three successive generations of Holstein-Friesian cattle
}

\begin{abstract}
The aim of the paper was to establish reproductive traits and their heritability during the three successive generations of Holstein-Friesian cattle. Research was conducted on the duration of pregnancy, service period and fertility intensity. In each generation there were 135 first calved cows. Service period and fertility intensity refers to the following calving. Significant differences were established $(\mathrm{P}<0.05)$ regarding duration of pregnancy between I and II generation. Significant $(\mathrm{P}<0.05)$ influence of season on duration of pregnancy and service period was established in I generation (1991), on duration of service period and fertility intensity in II generation (1996) and on duration of pregnancy and service period in III generation (2000). Season effect (summer) was established for all traits of fertility in II generation $(\mathrm{P}<0.05)$. The season (spring) had influence on duration of pregnancy $(\mathrm{P}<0.05)$ and summer had an influence on duration of service period and fertility intensity, and winter effected the duration of service period $(\mathrm{P}<0.05)$ in III generation. Values of heritability coefficients are pretty low for all generations. Considerably greater values for heritability were established for service period and intensity of fertility of cows per generations.
\end{abstract}

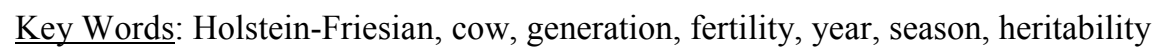

\section{Zusammenfassung}

Titel der Arbeit: Erblichkeit einiger Fruchtbarkeitsmerkmale in drei aufeinander folgenden Generationen von Holstein-Friesian Kühen

Ziel der Untersuchungen war die Schätzung der Heritabilität von Fruchtbarkeitsmerkmalen in drei aufeinander folgenden Generationen von Holstein-Friesian Kühen. Erfasst wurden die Merkmale Trächtigkeitsdauer, Güstzeit und Zwischenkalbezeit von je 135 erstabkalbenden Tieren je Generation. Die Merkmale Güstzeit und Zwischenkalbezeit beziehen sich auf die nachfolgende Trächtigkeit. Signifikante Unterschiede $(\mathrm{P}<0,05)$ ergaben sich für die Trächtigkeitsdauer zwischen der ersten und zweiten Generation. Signifikante Einflüsse wurden hinsichtlich der Saison auf die Trächtigkeitsdauer in der ersten Generation (1991), auf die Dauer der Güstzeit und die Zwischenkalbezeit in der zweiten Generation (1996) und die Trächtigkeitsdauer und Güstzeit in der dritten Generation (2000) festgestellt. In der zweiten Generation wurden Saisoneffekte (Sommer) bei allen Fruchtbarkeitsmerkmalen nachgewiesen. Ein signifikanter Einfluss ergab sich bei der Trächtigkeitsdauer hinsichtlich der Jahreszeit (Frühling). Ebenso konnte für den Sommer ein Einfluss auf die Güstzeit sowie die Zwischenkalbezeit und in der dritten Generation auf die Güstzeit nachgewiesen werden. Für alle untersuchten Fruchtbarkeitsmerkmale wurden in allen Generationen niedrige Heritabilitätswerte geschätzt. Gegenüber der Trächtigkeitsdauer lagen die Schätzwerte für die Güstzeit und die Zwischkalbezeit relativ höher.

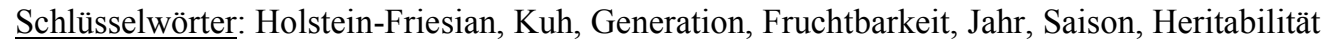

\section{Introduction}

The question of milk production and cow fertility is a constant problem in cattle breeding especially from the economical point of view. Considering the inheritance of fertility BERGFELD and KLUNKER (2002) thinks that infertility brings greatest economical damage to farm. It is reflected on the yearly production of milk, production of calves for breeding purposes or market, and indirectly on possible selection differential. Culling of cow because of their low fertility traits is the second and most frequent factor (first is low production), LAZAREVIC (1983). About 30 
criteria can be used for testing cow fertility traits. However, when choosing the criterion for estimation of fertility it is important that they should be objective, accurate, cheap, simple and applicable to great number of animals. It is also important that fertility belongs to traits with constant variations, that they can be measured in the youth so that the selection could be made the earliest possible. Besides it is desirable that these measures could be repeated, that is, that repeated control is possible.

Dairy industry dramatically changed during the last decade of the 20 century (M.C.LUCY, 2001). Milk production per cow increased due to improved management, better nutrition and intensive selection. Farms are bigger by 30\%. Greater milk production influenced the decrease in fertility (greatest milk production - lowest fertility). M.C.LUCY (2001) suggests that it is necessary to pay attention to oestrus cycle, metabolic effects of lactation on reproduction, mechanisms which link the diseases with reproduction as well as early embryo death.

Adequate application of modern breeding programs in improving cattle, as well as estimation of genetic potentials of cows and bulls would contribute to considerably more rapid improvement of production of milk and fertility (BERGFELD and KLUNKER, 2002). Heritability coefficient is one of the major parameters in every population. To determine heritability is significant in application of different proceedings in improving all kinds of animals, and especially cattle.

The aim of this research is to establish the traits of fertility in cows and their heritability in population of Holstein-Friesian cattle in three successive generations. These investigations are rather rare in our country today so we think it very important to deal with this issue in more detail.

\section{Material and Methods}

Trials were conducted on the state owned agricultural farm in the Republic of Serbia. Holstein-Friesian cattle had been raised on this farm from 1957, when first contingency of pregnant heifers (70 animals) was imported from Holland. During the first years (10-15) cows and heifers were inseminated with semen from Holland and Germany, and during the last two decades of the 20th century with imported semen from USA and Canada, as well as with obtained semen from imported bulls from these countries.

The investigations included animals raised on the farm from 1990 to 2001. Conditions of keeping, nutrition and care were almost equal, that is customary for state owned firms in the Republic of Serbia. In trials were used cows in the course of three successive generations of utilization, ie., I generation - dams, II generation - daughters and III generation - granddaughters. In every generation there was 135 animals, what makes total of 405 cows. Following fertility traits were investigated: duration of pregnancy, service period and fertility intensity. Duration of pregnancy concerned first pregnancy while other traits concerned the period between the first calving and next successful conception, that is between the first and second calving.

Data statistical analysis was performed by the method of the least squares (LSMLMW, HARVEY, 1988), by the use of model with fixed effect of factors on observed traits, and the results were obtained by the use of following model:

$$
\begin{array}{ll}
\mathrm{Y}_{\mathrm{ijkl}} & =\mu+\mathrm{G}_{\mathrm{i}}+\mathrm{S}_{\mathrm{j}}+\mathrm{O}_{\mathrm{k}}+\mathrm{b}_{1}\left(\mathrm{x}_{1}-\mathrm{x}_{2}\right) \mathrm{e}_{\mathrm{ijk}} \\
\mu & =\text { general mean value } \\
\mathrm{G}_{\mathrm{i}} & =\text { fixed effect of calving year }
\end{array}
$$




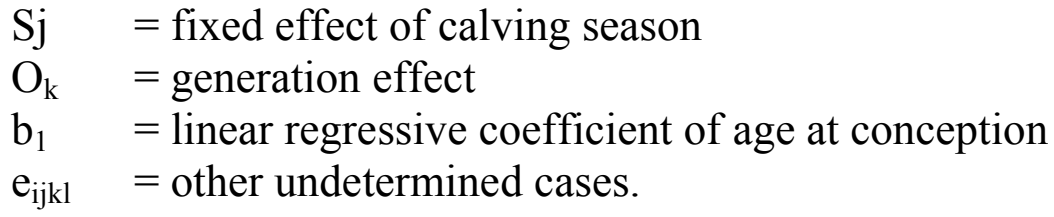

Results

Average values and variability of investigated traits of fertility in three successive generations are shown in Table 1.

Table 1

LS mean values and variability of traits of fertility observed per generations (LSM Mittelwerte und Variabilität der Fruchtbarkeitsmerkmale je Generation)

\begin{tabular}{lccccccccc}
\hline Generation & \multicolumn{3}{c}{ Duration of pregnancy, days } & \multicolumn{2}{c}{ Service period, days } & \multicolumn{3}{c}{ Interval between calvings, } \\
& \multicolumn{4}{c}{} & \multicolumn{3}{c}{ days } \\
\hline & $\mathrm{X}$ & $\mathrm{Sd}$ & variations & $\mathrm{X}$ & $\mathrm{Sd}$ & variations & $\mathrm{X}$ & $\mathrm{Sd}$ & variations \\
\hline Dams & 276.98 & 6.88 & $250-298$ & 138.92 & 86.10 & $36-374$ & 415.89 & 94.92 & $306-679$ \\
Daughters & 275.24 & 6.08 & $258-296$ & 126.98 & 74.01 & $24-326$ & 403.28 & 75.74 & $304-584$ \\
Granddaughters & 276.21 & 8.00 & $254-305$ & 125.00 & 74.92 & $25-355$ & 401.31 & 74.89 & $307-627$ \\
\hline
\end{tabular}

Observed per generations duration of pregnancy differs in certain systems. Longest duration of pregnancy was in I generation (dams) and shortest in II generations (daughters), while the III generation (granddaughters) was between these two values. On the basis of these results significant difference was established between I and II generation $(\mathrm{P}<0.05)$, while between I and III and II and III there is no difference $(\mathrm{P}>0.05)$. Sizes of standard deviations differ in generations in certain level. The reason for this is pretty wide variation in duration of pregnancy per generations (from 250 to 305 days).

Service period in these investigations (Table 1) was longest in I generation (138.92 days) and it gradually became shorter, so that it was shorter in III generation (125 days). These differences are significant $(\mathrm{P}<0.05)$. Nevertheless, it should be noted that standard deviation expressed in days has pretty high values, what is certainly the result of high absolute varying of service period (24 to 374 days). This indicates the possibility of shortening service period and more efficient utilization of cows in this population, that is, cows per generation.

Interval between calving, that is, the intensity of fertility is a product both of duration of pregnancy and service period. Because of that obtained values of duration of interval between calvings have similar tendency to breeding values. Longest duration of interval between calvings is in I generation, and shortest in III generation (Table 1). Significant differences were established only between I and III generations $(\mathrm{P}<0.05)$. Absolute varying is strongly expressed (306-769 days), and it is greatest in I generation, although the varying of duration of interval between calving is rather long in next generations (304 -627 days).

The effect of year (Table 2$)$ significantly $(\mathrm{P}<0.05)$ expressed deviations from average for duration of pregnancy ( +2.0 days) and service period (-8.16 days) only in 1991 in animals of I generation. Other deviations (+-) for investigated traits ranged on the average and were insignificant. $(\mathrm{P}>0.05)$.

The year effect in II generation showed no significance $(\mathrm{P}>0.05)$ on the duration of pregnancy. However, service period lasted 122.94 days in 1996 and deviated from average for 7.36 days $(\mathrm{P}<0.05)$. Also, the interval between calving in the same year 
deviated from average by 8.95 days $(\mathrm{P}<0.05)$ and was shortest, that is it lasted only 399,88 days what is greatest deviation from average observed per generations.

Table 2

Effect of year as LSM deviations (ĉi) on the fertility traits (Jahreseffekt als LSM Abweichung (ĉi) der Fruchtbarkeitsmerkmale)

\begin{tabular}{|c|c|c|c|c|c|}
\hline & \multicolumn{2}{|c|}{$\begin{array}{c}\text { Duration of } \\
\text { Pregnancy, days }\end{array}$} & Service period, days & \multicolumn{2}{|c|}{$\begin{array}{c}\text { Interval between calvings, } \\
\text { days }\end{array}$} \\
\hline $\bar{\mu}$ & \multicolumn{2}{|c|}{276.14} & 130.30 & \multicolumn{2}{|l|}{408.83} \\
\hline \multirow[t]{2}{*}{ S.E. } & \multicolumn{2}{|c|}{0.52} & 5.81 & \multicolumn{2}{|l|}{6.06} \\
\hline & \multicolumn{5}{|c|}{$\mathrm{D}$ a $\mathrm{m} \mathrm{s}$} \\
\hline Season & $\hat{\mathrm{c} i}$ & LSM & LSM & $\hat{\mathrm{C}} \mathrm{i}$ & LSM \\
\hline 1990 & -0.29 & 278.85 & 132.15 & 0.07 & 408.90 \\
\hline 1991 & $2.00 *$ & 278.14 & 122.14 & 6.55 & 400.28 \\
\hline 1992 & 0.01 & 276.15 & 133.12 & 0.89 & 409.27 \\
\hline 1993 & -0.20 & 275.94 & 130.45 & -0.05 & 406.39 \\
\hline$*=\mathrm{P}<0.05$ & \multicolumn{5}{|c|}{$\mathrm{D} a \mathrm{ught}$ e $\mathrm{r} s$} \\
\hline 1994 & -0.22 & 275.72 & 135.17 & 4.38 & 410.82 \\
\hline 1995 & 0.88 & 277.02 & 134.11 & -1.42 & 411.02 \\
\hline 1996 & 0.80 & 276.94 & 122.94 & $-8.95 *$ & 399.88 \\
\hline 1997 & -0.80 & 275.83 & 134.15 & -1.46 & 409.98 \\
\hline$*=\mathrm{P}<0.05$ & \multicolumn{5}{|c|}{ G r a nd a u g h e r s } \\
\hline 1998 & -0.08 & 276.06 & 133.01 & 0.24 & 409.07 \\
\hline 1999 & $1.52 *$ & 277.65 & 129.11 & -2.07 & 406.76 \\
\hline 2000 & 1.86 & 278.00 & 125.32 & -5.51 & 403.32 \\
\hline 2001 & -0.22 & 275.92 & 134.04 & 1.18 & 409.96 \\
\hline
\end{tabular}

Table 3

Effect of season as LSM deviation (ĉi) on the fertility traits (Saisoneffekt als LSM Abweichung (ĉi) der Fruchtbarkeitsmerkmale)

\begin{tabular}{|c|c|c|c|c|c|}
\hline & \multicolumn{2}{|c|}{$\begin{array}{c}\text { Duration of pregnancy, } \\
\text { days }\end{array}$} & Service period, days & \multicolumn{2}{|c|}{$\begin{array}{c}\text { Interval between calvings, } \\
\text { days }\end{array}$} \\
\hline$\mu$ & \multicolumn{2}{|c|}{276.14} & 130.30 & \multicolumn{2}{|c|}{408.83} \\
\hline S.E. & \multicolumn{2}{|c|}{0.52} & 5.81 & \multicolumn{2}{|c|}{6.06} \\
\hline & \multicolumn{5}{|c|}{$\mathrm{D}$ a $\mathrm{m} \mathrm{s}$} \\
\hline Season & ĉi & LSM & LSM & $\hat{\mathrm{C}} \mathrm{i}$ & LSM \\
\hline Spring & -0.27 & 275.87 & 129.21 & -3.75 & 405.08 \\
\hline Summer & 0.88 & 277.02 & 135.04 & 3.23 & 412.06 \\
\hline Autumn & 0.76 & 276.90 & 130.09 & 0.16 & 406.99 \\
\hline Winter & -0.25 & 275.89 & 129.80 & -1.14 & 405.69 \\
\hline \multicolumn{6}{|c|}{$\mathrm{D} a \mathrm{ught}$ e r s } \\
\hline Spring & 0.79 & 276.93 & 134.17 & 4.27 & 411.10 \\
\hline Summer & $1.66^{*}$ & 277.80 & $-10.28 *$ & $-8.01 *$ & 398.82 \\
\hline Autumn & -1.00 & 275.14 & 129.80 & -3.89 & 404.94 \\
\hline Winter & -0.14 & 276.00 & 131.65 & 0.82 & 407.65 \\
\hline$* \mathrm{P}=<0.05$ & \multicolumn{5}{|c|}{ Gra $n d d a u g h$ e $r$ s } \\
\hline Spring & $1.55^{*}$ & 277.69 & 129.03 & -0.11 & 406.72 \\
\hline Summer & 0.00 & 276.14 & $-10.99 *$ & $-10.68 *$ & 396.15 \\
\hline Autumn & -0.56 & 275.58 & 134.04 & -0.21 & 409.62 \\
\hline Winter & -0.34 & 275.80 & 136.12 & 3.09 & 411.92 \\
\hline
\end{tabular}

The year effect has significantly $(\mathrm{P}<0.05)$ expressed action on the traits of duration of pregnancy in 1999 and 2000, as well as on the trait of duration of service period in 2000. The duration of pregnancy deviated from average +1.52 days, that is +1.86 days, and duration of service period -4.98 days.

The effect of season showed no significance $(\mathrm{P}>0.05)$ on investigated traits of fertility in animals of I generation (Table 3). 
Significant effect of season (summer) was established in II generation for all investigated traits of fertility $(\mathrm{P}<0.05)$. Animals of this generation, under the influence of season (summer) in regard to the average of population, accomplished longer pregnancy for +1.66 days, service period and fertility intensity shorter by -1028 days, ie., -8.01 days $(\mathrm{P}<0.05)$. Other deviations $(+-)$ from average for investigated traits under the influence of season were not significant $(\mathrm{P}>0.05)$.

The season (spring) had an effect in animals of III generation on the duration of pregnancy $(\mathrm{P}<0.05)$, and summer on the duration of service period and interval between calving $(\mathrm{P}<0.05)$, while winter on the duration of service period $(\mathrm{P}<0.05)$. The above mentioned deviations from average under the influence of season were + 1.55 days, -10.99 days, -10.68 days and -5.82 days respectively $(\mathrm{P}<0.05)$.

Heritability of reproductive traits in this species of farm animals is low on average what is confirmed also by our results (Table 4).

Table 4

Heritability and heritability errors for reproductive traits (Heritabilität und Schätzfehler für Fruchtbarkeitsmerkmale)

\begin{tabular}{lcccccr}
\hline Trait & \multicolumn{2}{c}{ Dams } & \multicolumn{2}{c}{ Daughters } & \multicolumn{2}{c}{ Grandaughters } \\
\hline & $\mathrm{h}^{2}$ & $\mathrm{Sh}^{2}$ & $\mathrm{~h}^{2}$ & $\mathrm{Sh}^{2}$ & $\mathrm{~h}^{2}$ & $\mathrm{Sh}^{2}$ \\
\hline $\begin{array}{l}\text { Duration of pregnancy, } \\
\text { days }\end{array}$ & 0.039 & 0.088 & -0.090 & 0.135 & 0.059 & 0.119 \\
\hline Service period, days & 0.145 & 0.089 & 0.176 & 0.104 & 0.108 & 0.090 \\
\hline $\begin{array}{l}\text { Interval between } \\
\text { calvings, days }\end{array}$ & 0.089 & 0.079 & 0.181 & 0.106 & 0.081 & 0.085 \\
\hline
\end{tabular}

Heritability of duration of pregnancy observed per generations is very low. Also it should be pointed out that heritability established in II generation has negative values $\left(\mathrm{h}^{2}=-0.090\right)$. Mean value of error in heritability is within the limits set for this trait.

Heritability values for service period are also low and positive. The smallest is the value in III generation $\left(h^{2}=0.108\right)$, and greatest in II generation $\left(h^{2}=0.176\right)$. It is known that service period depends on several various factors what was reflected also on the size of heritability whose values indicate stronger action of external factors than heritability itself. Mean errors of heritability are pretty low, that is they confirm the accuracy and size of heritability.

Heritability of intensity of fertility is also rather low in I and III generation, while in II generation this value is somewhat higher.

\section{Discussion}

Modern selection-breeding programs in cattle breeding pay special attention to the estimation of heritability coefficients. Heritability coefficient is one of major parameters in every population (AMIN et al., 2000; SÖLKNER et al., 2000). In research work there is a hypothesis that selection in the direction of increasing milk yield automatically leads to decrease in fertility. This is explained by physiological and hormonal relationship of these traits (PAVUNA et al., 1978). On the other hand, low coefficients of heritability of fertility indicate that many external factors effect this trait (MILOJIC et al., 1984; LAZAREVIC, 1983; MISCEVIC, 1995; DEMANTAWEWA and BERGER, 1998; GOYACHE and GUTIERREZ, 2001).

Duration of pregnancy considerably varies per races and some other factors also influence this trait. In our investigations certain differences per generations for the same race were established. According to HILJKEVIČ and ČOHATARIDI (1982) for 
White Black cattle it was 279,2 days on average, MILOJIĆ et al (1984) 276.5 days, LAZAREVIĆ (1983) 278 days. The level of heritability for the fertility traits is rather low. According to CAMPAS et al. (1994) heritability for reproductive traits ranged from 0.025 to 0.056 while the correlations between productive and reproductive traits were also low and insignificant. Similar research to our research were conducted by MILOJIĆ et al. (1984) for the first lactation of white black cattle when they have found out that heritability for duration of pregnancy was low and lasted 0.042. Authors also observed that other factors considerably more influence the duration of pregnancy than the influence of heritability.

Service period in our research varied in wide limits, and the heritability coefficient was rather low. Service period for white black cattle ranged from 99-101 days according to calving in order. Heritability was $0.01,0.05$ and 0.09 , for first, second and next lactations, what is lower than our values (STOJIC et al., 1993). Also service period was longer in cows fertilized in summer than in winter and spring and differences are up to 10 days. These results are very similar to our researches for the animals of II generation (Table 3).

Similar values of duration of service period to our results for the same breed in I lactation were obtained by BERGER et al. (1981) and WASHBURN et al. (2002), when it was on average 131 days that is 124 days, while according to BOLDIREV and NEKRASOV (1990) it varied from 74 to 124 days and they established size of heritability for duration of service period of 0.097 to 0.05 , and MARTI and FUNK (1994), 0.05 and it was higher for animals with greater milk production, while the regression of service period to reproductive traits was higher in herds with lower milk production. Similar values of heritability to our research and research of above cited authors was established also by DEMATAWEWA and BERGER (1998), while the coefficient of repeatability for service period was 0.12 . Because of that it could be said that conducting selection (at which the duration of service period should also be taken as a criterion) had a small effect in improving the milk production.

Inheritance of fertility intensity varies from 0.00 to 0.32 and from 0.072 to 0.380 (MILOJIĆ et al., 1984), what is in accordance with our results, as well as the results of MOORE et al. (1991), HAYES et al. (1992) and STOJIĆ (1993). Various factors influence the intensity of fertility such as the choice of breeding bulls, interval from calving to first oestrus, then from first oestrus to successful conception, as well as the number of inseminations. However, MILOJIĆ et al. (1984), says that intensity of fertility can be influenced also by special treatment of every animal on the farm. The authors also state that the month of calving and conception, age at calving and maximum production of milk do not influence the intensity of fertility.

The issue of cattle fertility was significant in the past, it is important now and it will remain so in the future. Improving of fertility would contribute a further increasing of production in cattle breeding. Genetic contribution of fertility is very important, but non-genetic methods must also be observed in improving cattle fertility.

\section{References}

AMIN, A. A.; GERE, T.; KISHIK, W.H.:

Additive genetic variance and covariance in some reproductive disorders in Hungarian Holstein Friesian using multi-trait animal model. Arch. Tierz., Dummerstorf 44 (2001) 5, 489-496

BERGER, P.J.; SHANKS, R.D.; FREEMAN, A.E.; LABEN, R.C.:

Genetic aspects of milk yield and reproductive performance. Journal of Dairy Science, 64 (1981), 114122 
BERGFELD, U.; KLUNKER, M.:

Bedeutung funktionaler Merkmale in der Rinderzucht und Möglichkeiten für deren züchterische Verbesserung. Arch. Tierz., Dummerstorf 45 (2002) Sonderheft, 60-67

BOLDIREV, M.K.; NEKRASOV, D.K.: Influence of early cow insemination on production and reproductive traits. Izvestija Timirjazevskoj seljsko hazjajstvenoj akademi, 1 (1990), 142-150

CAMPAS, M.S.; WILCOX, C.J.; BECERRIL, C.M.; DIZ, A.:

Genetic parameters for yield and reproductive traits of Holstein and Jersey cattle in Florida. Journal of Dairy Science, 77 (1994), 867-873

DEMATAWEWA, C.M.; BERGER, P.J.:

Genetic and phenotypic parameters for 305-day yield, fertility, and survival in Holstein. Journal of Dairy Science, 81 (1998), 2700-2709

GOYACHE, F.; GUTIERREZ, J.P.:

Heritability of reproductive traits in Asturiana de los Valles beef cattle breed. Arch. Tierz., Dummerstorf 44 (2001) 5, 489-496

HARVEY, W.R.:

Mixed Model Least Squares and Maximum Likelyhood Computer Program. User's Guide for LSMLMW PC-1 Version, 1988

HAYES, J.F.; CUE, R.I.; MONARDES, H.G.:

Estimates of Repeatibility of Reproductive Measures in Canadian Holstein. Journal of Diary Science, 75 (1992), 1701-1706

HILJKEVIČ, H.M., ČOHATARIDI, G.N.:

Evaluation of Swiss Simmetal and Black-White calves. Životnovodstvo, 2 (1982), 35-36

LAZAREVIĆ, R.:

Influence of milk production on some reproductive characteristics and calves weight on calving at Blach-White cows. VI jugoslovenska stočarska konferencija, 588 (1983), 69-76

LUCY, M.C.:

Reproductive loss in high-producing dairy cattle: where will it end? Journal of Dairy Science, 84 (2001), 1277-1293

MILOJIĆ, M.; LAZAREVIĆ, R.; LATINOVIĆ, D.:

Heritability and connection of the fertility traits in Black and White cows. Savremena poljoprivreda, 32 (1984), 485-493

MARTI, C.F.; FUNK, D.A.:

Relationship between production and days open at different levels of herd production. Journal of Dairy Science, 77 (1994), 1682-1690

MIŠČEVIĆ, B.:

Variance, covariance components and genetic trend of dairy characteristics during first and next lactations i Simmental cows. Doctors disertation, Novi Sad, (1995), 1-96

MOORE, R.K.; KENEDY, B.W.; SHAFER, L.R.; MODEY, J.E.:

Relationships Between Age and Body Weight at Calving and Production in First Lactation Ayrshire and Holstein. Journal of Dairy Science, 74 (1991), 269-278

PAVUNA, H.; ŠIC, R.; ŠIMUNIĆ, B.; KOVAČEVIĆ, M.:

Good dairy characteristics versus higher production and better reproduction. Stočarstvo, 32 (1978), 147158

SÖLKNER, J., MIESENBERGER, J.; WILLAM, A.; FUERST, S.H.; BAUMUNG, R.: Total merit indices in dual purpose cattle. Arch. Tierz., Dummerstorf 43 (2000) 6, 597-608

STOJIĆ, P.; KATIĆ, M.; LAZAREVIĆ, LJ.; LATINOVIĆ, D.; VAJIĆ, Z.:

Influence of genotype, lactation and age at calving on service periode and insemination index. Biotehnologija u stočarstvu, 9 (1993), 11-18

WASHBURN, S.P.; SILVIA, W.J.; BROWN, C.H.; McDANIEL, B.T.; McALLISTER, A.J.:

Trends in reproductive performance in Southeastern Holstein and Jersey DHI herds. Journal of Dairy Science, 85 (2002), 244-251

Received: 2004-01-06

Accepted: 2005-01-12

Corresponding author

Academician RATKO LAZAREVIC, DSc

Faculty of Technology, Feed Technology Department, University of Novi Sad

21000 Novi Sad, Bulevar Cara Lazara 1

Serbia and Montenegro

E-mail: agricons@yubc.net 